\title{
War at the Background of Europe: The Crisis of Mali
}

\author{
BESENYÖ János ${ }^{1}$
}

\begin{abstract}
In 2012 the seemingly stable country of Mali experienced a sudden collapse, this along with the declaration of independence of the brand new Tuareg state, the massive spread of extreme Islamism shocked the international community. Initial disbelief gave way to the UN Security Council's resolution to restore Mali's terri-torial integrity. Fueled by the fear of a greater and bloodier conflict and its over- spill, limited military operations began. Along with the Economic Community of West African State-led operation, the country's former colonial master, France, began its own controversial military operation. Many people think that by doing so, France is trying to prove itself a great power and able to intervene on the world political stage according to its own diplomatic interest and being a force to contend with. Others however think that France is facing another Indochina-like fiasco in Mali. Who is right, will be determined by the failure or the success of the current operations and by the results of the restoration afterward. In this paper I would like to clarify the reasons for the events taking place in the country, their dynamics and possible consequences.

keywords: Mali, AQIM, Boko Haram, Tuareg, Azawad, rebellion, France, USA, European Union, peacekeeping, Operation Serval,
\end{abstract}

\section{Mali}

The country is located in the West African territory; bordered from the North by Algeria (1376 km), from the South by Guinea $(858 \mathrm{~km})$, Ivory Coast $(532 \mathrm{~km})$, and Burkina Faso $(1000 \mathrm{~km})$, from the East by Niger $(821 \mathrm{~km})$, from the West by Mauritania $(2237 \mathrm{~km})$ and Senegal $(419 \mathrm{~km})$. The land area of the country is 1,241,190 square kilometers, which is considered the world's $24^{\text {th }}$ largest state, but only $4 \%$ (2360 square kilometers) of that is cul- tivated, despite the fact that an additional 1,000,000 hectares are arable, according to some estimates. (IMF, 2011) It does not have a coast line, but the country is crossed by the river Niger. The climate varies from subtropical to desert. The summer is a dry season from Febru- ary to June, the rainy season begins from June to November and from November to February a dry, and cool period starts. (CIA, 2013) The average annual temperature is $27.5^{\circ} \mathrm{C}$, and the hottest month of the year is April, when $39^{\circ} \mathrm{C}$ counts as typical. The coldest months are December and January, when temperature averages $16^{\circ} \mathrm{C}$. (ACAPS, 2012)

The country is mostly made up of flat areas, in the north-west, semi deserts stretch into the Sahara, the south is more savannah type - limited agriculture is found here - and the north-east is covered by mountains.

\footnotetext{
1 besenyo.janos@gmail.com

BESENYŐ János: War at the Background of Europe: The Crisis of Mali
}

Mali is one of world's 25 poorest countries, its main sources of revenue are mostly gold mining (Bertelsmann Stiftung, 2012: 21) and exporting agricultural products (cotton, live- stock). The country has major exploited mineral resources such as gold, phosphates, kaolin, salt, uranium, gypsum, granite, and also significant are the non-exploited stocks of bauxite, iron ore, manganese, tin and copper. Along the Niger River there is farming (cotton, millet, rice, corn, citrus fruits, vegetables, groundnuts, gum arabic, shea nuts, cattle, sheep and goats), fishing and foresting, and they gain significant energy from the hydroelectric power plants (Félou, Taoussa) operating here. Mali has been greatly affected by the drought in the recent years, which caused desertification and livestock farmers migfation. The country heavily depends on the aid provided by international organizations. (Bertelsmann Stiftung, 2012: 25) With IMF support from 1996 to 2010 , the country - with government's structural reform and increase of efficiency — was able to produce an average $5 \%$ economic growth but this was not sustainable due to the increased security concerns.(IMF, 2011) In 2011, the country realized only a $2.6 \%$ growth, in 2012; it had a $5.9 \%$ decline forecast. The IMF approved immediate emergency aid at the end of 2012 to somewhat reduce the damage caused by the drought, the military putsch and by the outbreak of fighting in the north. (IMF, 2012) For these reasons, the commercial and tourism sector suffered substantial losses. The communication sector strength- ened considerably in recent years, however the access to LAN line phone or internet service is still limited, although the majority of the population possesses mobile phones. The country's major economic partners are: China, France, Senegal, South Korea, Indonesia and Ivory Cost.

The transportation service is underdeveloped. The country has a narrow-gauge railway line (593 km), but only a small portion of the roads are paved (less than $3597 \mathrm{~km}$ out of $18912 \mathrm{~km}$ ), and also the Niger River is only navigable during the rainy seasons. The sea can only be accessed through Senegal which has proved to be problematic for the 
country numerous times. (Diallo, 2008: 46)

The people living here, originate from different tribes so the composition of the popula- tion is very heterogeneous. The main groups of the population are Mande - Bambara, Son- inke, Malinka - 50\%, the Fulani (Pelu) 17\%, Voltaic 12\%, the Song Hai 6\%, the Tuaregs, Arabs 10\%, and several other small tribes (Bozo, Dogon, Tukolor, etc.). (Imperato, 1996:

16-17) The French living here represent 5\%. The majority of the population speaks French and Bambara, but many other African languages are also spoken. According to 2012's esti- mates, the country's population is 15,494,466 people, of which $47.8 \%$ are under the age of

$14,49.2 \%$ are between the age of 14-64 and less than 35\% are over 65. 1,628,000 people live in the capital. $36 \%$ of the population lives in cities, the rest make a living out off agri- culture and nomadic livestock (10\% of the population). (CIA, 2013) The growth rate of the population is $3.2 \%$, which yields a major problem to the already week social care network system. The illiteracy rate is high, since only $24 \%$ of the total population are able to write and read. ${ }^{2}$

Therefore, state-run or private television and radio's role and influence are very high. (Bertelsmann Stiftung, 2012: 10)

Education, especially in the northern territory — inhabited by Tuaregs and belonging to the underdeveloped part of country - is very low. (IMF, 2011) A substantial part of the population is Muslim (90\%), mainly Sunnites belonging to the Maliki faction, which was significantly affected by Sufism and other earlier tribal religions. In recent years, the number of radicalized Muslims has increased, and they do not hesitate

BESENYÖ János: War at the Background of Europe: The Crisis of Mali

to use violence in the interest of protecting and propagating their faith and beliefs. Although Mali is a secular state, the Muslim religious leaders have significant influence, which was shown in 2009 when they vetoed the Family Code which was amended by the government. Christianity and Animism (together 10\%) are practiced by a minority. ${ }^{3}$

Health care is underdeveloped, which is shown by the ratio of the person per hospital bed ratio which is 2000 to 1 . Officially $1 \%$ of the population is HIV positive, but the prevalence rate is somewhat higher than that. Diseases such as malaria, viral encephalitis, yellow fever, cholera, and various infections caused by untreated food and water are considered common.

The country's military force consists of three main units: the army, the air force and the National Guard. In the army, units of conscripts and volunteer (professional) soldiers serve. Compulsory military service begins at the age of 18 and the service time for enlisted soldiers is uniformly 2 years. Although $1.9 \%$ of the GDP is spent on military expenditure, the staff is underpaid, poorly trained and unmotivated. A significant part of the officer corps are unedu-cated and corrupt, which was demonstrated during the Northern military operations. During the 1991 changes, the army itself led the democratic change, which resulted in significant positions for them in the state leadership, but did not bring any positive changes to the army itself. Today, the number of military service personnel has declined to 7700 due to military losses and desertions. (Diarra, 2012: 15-16) After the last period, it would be essential to rebuild the shattered military command and control system. It would be necessary to reed- ucate, remap and rearm them to be able to effectively operate against the Islamist extremist occupiers in the Northern provinces. (ACAPS, 2012)

Illegal migration and the smuggling of arms and drugs, other commercial products - ve- hicles, fuel, food, cigarettes, alcohol, livestock etc. - cause a major problem for the govern- ment. A great number of these smugglers are Tuaregs who understand the desert very well, and have been known for centuries for escorting, and robbing caravans and desert trafficking. (Lohman, 2011: 6) (Diarra, 2012: 2) Destabilizing terrorism filled with Islamist ideology, kidnapping, organized crime networks covering the whole country and the high degree of corruption also cause problems in the region. (Bertelsmann Stiftung, 2012:19)

\section{The Tuaregs}

In order to better understand the recently escalated conflict, we must understand the ethnic group, the Tuaregs, which caused its out-break. They are an ethnic group with Berber origins, whose members are composed mainly of Mali, Niger,

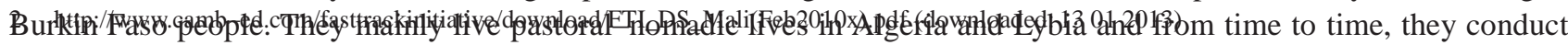
armed up- risings in the territory of Mali and Niger for their rights and for the possession of the territory known as 248zawad". (Ilahiane, 2006: 133-138) (Imperato, 1996: 41, 234) Some Astkimases 18a)gg(est13that they are a group of 1.5 to 2 million people, most of whom settled in Mali and Niger. (Bondersholt, Gyldenholm, 2012: 3) In Mali according to some estimates, 600,000 people make up its population, but this has not been confirmed by a census. (Keita, 1998: 6) The armed activities are a century-old tradition for this group, and the warriors (imushar) are the most well respected members of their society. Although they spend most of their life on the road, they practice farming in their settlements.

BESENYÖ János: War at the Background of Europe: The Crisis of Mali

The name Tuareg derives from the Lybian desert city called Targa — in Arabic it means "Comes from Targa" but some people just call them the 'blue men of the desert', for the colors they wear, or they may call them 'masked men' for their characteristic protec- tive masks worn on their faces. They call themselves the "free people" - 
Amazigh. It is an appropriate name since this group of people is well known for their desire of freedom, and also because they do not recognize any authority above themselves. The Tuaregs live in a tribal system and they have created 7 major alliances and name them by their geographical position. The allied tribes can be divided up into tribes, fractions and families. (Diallo,

2008: 43-44, 50-53) The sort of feudal type of tribe can be divided into 4 classes. The no- bles own the land, the animals and they control the tribe. The second group of the tribe in- cludes the vassals, people who take care of the noble's land and animals. ${ }^{4}$ (ACAPS, 2012) A third group includes religious leaders, teachers and in the fourth group are blacksmiths and craftsmen - tent, carpet, weapon, jewelry makers. The tribe is directed by its leader (Amenokal), who belongs to the nobles and exercises political rights and judges case laws, and also acts as an intermediary between the nobles and the vassals. In the decision making process, however he must consult with the council of the tribe (Arollan), which consists of nobles, and prior to making decisions. The tribal leader can only be a man, but it is calculated based on matrilineal descent as to who is considered a Tuareg. This indicates their respect and honor toward women, who in the Tuareg traditions are 'guardians' (Schraeder,

2011: 185) with a high degree of autonomy and, as opposed to other Arab tribes, they have their own possessions, which can be retained after divorce according to the marriage con- tract. Women have the right to decide to whom they wish to be married, they do not have to hide their faces and they can work even without the permission of their husbands. Since polygamy does not exist among Tuaregs, they can only have one wife. The Tuaregs are famous warriors and artists, men are still proud of their fighting skills, their hand-forged sword is their most precious belonging. Some blades are passed from generation to gener- ation. ${ }^{5}$ Most of them still wear the famous blue clothing (Tagelmust), but more and more people, especially youngsters are wearing western clothes. Furthermore, they are leaving the desert cities or moving abroad.

The majority of Tuaregs became Muslim in the XVI. Century, but they retained their pre-Islamic habits and beliefs. ${ }^{6}$ (Scelto, 2002: 1) They believe in various spirits such as the spirit of nature (Kel Asuf), and they have various rituals for almost every occasion (birth, naming, wedding, Muslim holidays, death, etc.). They have their own language (Tamazight, Tamashek) which is one of the oldest languages, it is at least 3500 years old, a fact proven by their writing (Tifinaagh). Developed in ancient times, that writes from right to left. (Ilahiane,

2006: 84-85) The different allied tribes speak different dialects of their language. From their

4 This group (according to estimates 800,000 capita) includes the former slaved-status blacks (Bell), whom

after the abolition of slavery remained with the tribe, under the rule of their former owner. Still they do not get paid for their work, but they provide them with catering and accommodation.

5 When I was serving as a peacekeeper in Western Sahara, I met with a Tuareg man, whose blade had a running wolf on it, a symbol which was the emboss of Passau sword making masters in the Middle Ages. It is possible that the blade was a part of a commercial deal or got to the Sahara as booty. In the time of the Turkish- Hungarian wars. In the late medieval period many Berber Tuaregs served in the Turkish auxiliary units, they did not get paid, but kept the loot. Their habit was to collect not only the undamaged arms but also the half- broken blades from the battlefields which were converted into one-handed swords. To this day, many such blades turn up in the markets, to the delight of European art dealers.

6 Some researcher believes that before the arrival of Islam the Tuaregs were Christian.

BESENYŐ János: War at the Background of Europe: The Crisis of Mali

trade and smuggling activities most of them are fluent in French and several other African

languages (Hausa, Songhai, Arabic) as well.

For centuries, the members of the ethnic group have been active participants in trading in the Sahara area and roam the five main trade routes, as traders, as caravan escorts and as robbers. The traders originally traded with artisans of gold, silver, jewelry, blue cloth, and salt traders, but in recent years, they switched to more profitable trading goods such as weapons, drugs, cigarettes, vehicles, fuel, and other contraband, and also they started guiding illegal human trafficking toward the European Union. In a changing world as an increasing number of people settled down they began farming animals, cultivating the land, or producing craft iron, wood, and jewelry products. Also they take work in the neighboring countries as guest workers.

Their population in Mali represents only a small portion of the total population, less than

$10 \%$ but this value is only an approximation as exact figures are not available. This is ex- plained partly because of their nomadic, roaming life, and partly because their distancing and separating themselves from the central government.

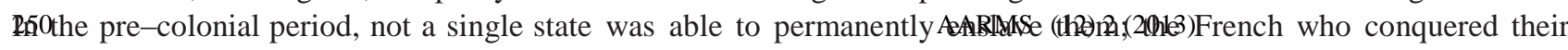
territory by the end of the 1800s, were only able to "pacify" them by 1917. (Bondersholt, Gyldenholm,

2012: 29-31); (Humpreys, Mohamed, 2003: 17) From then on, they have been marginalized as an ethnic group that is unable to comply with European laws. On their the territory a mil- itary administration operated, which tried to regulate and keep under control every aspect of Tuareg life; it taxed their caravans, confiscated their camels for military purposes, took their pastures, which they had been using for centuries, then took part of the men to work as forced labor or to military service. They tried to permanently resettle them, but that did not work out. Later, the French planned to create an independent Tuareg entity to completely separate them, but this was never fully implemented. Since the French obstructed them from trading, they converted to nomadic shepherding so they lost their previous role and their influence significantly reduced in Sahel. (Diallo, 2008: 3) After this, it is no surprise that they did not gain roles in the country's governances, even after the declaration of independence, new political positions were taken by the ones living in the Southern territories. In the 1990s, and also between 2006 and 2009, with Algerian intercession, they reached an agreement with the government to provide them regional autonomy and for the armed forces to integrate them into the military 
(army, national guard, police). The government also agreed to provide them greater financial support for the underdeveloped northern territories. However these agree- ments have not been complied with so they became more and more dissatisfied and took up arms again.

\section{The Tuareg Rebellions}

Since Mali's independence, the Tuaregs have rebelled several times against the government, something which has led to cruel bloody battles and considerable sacrifices on both sides. (Boukhars, 2012: 4-5) The first uprising immediately broke out after obtaining independence in 1963, because the Northerners - including the Tuaregs - were not, or in only very limit- ed numbers, able to occupy the new state's government positions and also they did not fit into the modernization strategy based on social ideology forced by the country's first president

BESENYÖ János: War at the Background of Europe: The Crisis of Mali

Modibo Keita. ${ }^{7}$ The new leadership did not support the nomadic lifestyle, since it considered it useless. Therefore, similar to the French, they tried to resettle the ones that continued roaming. (Bondersholt, Gyldenholm, 2012: 4-5); (Schraeder, 2011: 180-181) Their land was taken into state property and they wanted to force the Tuaregs into cultivation by prohibiting roaming, grazing livestock and forcing them to free their slaves who served their tribes. The Tuaregs felt that the country's independence did not bring them any good; they felt that their former colonizers were replaced by new ones from South Mali. Uprisings unleashed by part of the marginalized Tuaregs (Iforas tribe) were brutally defeated by the government after almost two years. ${ }^{8}$ (Keita, 1998: 10); (Imperato, 1996: 235) They not only bombed them but poisoned their artesian wells and government soldiers held public executions. (Schraed- er, 2011: 181-182) The government believed that it could handle the situation by military means, therefore, negotiations between the opposite parties were out of the question. In those clashes more than 1000 Tuaregs lost their lives and thousands more fled to Algeria as well as neighboring countries. (Keita, 1998: 9-11); (Humpreys, Mohamed, 2003: 18) This event, at that time, did not catch the attention of the international community because it was occupied with ones in the Congo and Cyprus. After repressing the rebellion in 1968, a military putsch replaced the previous government and the new president, Moussa Traoré, introduced military governance in the Northern Territory, where outsiders were not allowed to enter until 1987 and where any means were allowed to suppress the aspiration of independence.

Many young people emigrated to Niger, Burkina Faso, Mauritania and Libya out of necessity, fleeing the destruction of their sheep during the drought period between 1970 and 1987, during which they lived in refugee camps for years. (Ilahiane, 2006: 40-41, 104-105) They created the Azawadi and Adrar Tuareg Liberation Movement (Mouvement Touareg de Libération de 1'Adrar et de l'Azawad), which aims at the creation of Tuareg Azawad. The Tuaregs did not receive any aid arriving into Mali; it was distributed in the more devel- oped southern areas between the government loyalists or were stolen by particular ministers. (Imperato, 1996: 4243) This is when the second Tuareg rebellion broke out provoked by some Tuaregs imprisonment. The Azawadi People's Liberation Movement's (Mouvement Populaire de Libération de 1'Azawad - MPLA) leader Iyad Ag Ghali, who is currently the commander of the Ansar Dine, played a leading role in the uprising. ${ }^{9}$ (Keita, 1998: 38-39) The MPLA's militants on June $28^{\text {th }} 1990$ attacked Mali's north-east Tideremen military base, then Ménaka city. In September, next to Tuxemene, they destroyed a 200 person military unit which resulted in many more young people joining Tuareg's forces, whose headcount soon reached 3000 people. This uprising was much better organized than the previous one and the rebels received almost unlimited support and modern Soviet light weapons from Libya. Mali's armed forces counted 6900 persons, the gendarmerie, 1800 persons, and the police,

1000 persons but they were not properly equipped and motivated. (Keita, 1998: 39) The gov-

7 The Northern provinces: Kidal, Gao and Timbuktu gives the country $2 / 3$ of its area, but only $10 \%$ of the total population lives there.

8 According to Lieutenant Colonel Kalifa Keita who was involved in the suppression of the second Tuareg rebellion, only 1,500 participated in the 1962 to 1964 armed conflicts because the Tuareg community was not able to consistently act against the government.

9 In the uprising several other minor organizations were involved, such as the Popular Front for the Liberation of Azawad (Le Front Populaire de Liberation de l'Azawad - FPLA) the National Liberation Front for Azawad (Le Front National de Liberation de l'Azawad - FNLA), Basic Autonomic Unified Front for the Liberation

AABMS Front (Le Front Islamique Arabe de l'Azawad - FIAA).

BESENYÖ János: War at the Background of Europe: The Crisis of Mali

ernment responded brutally to the Tuaregs initial success. A state of emergency was declared and they launched an immediate attack against the Tuareg community. (Imperato, 1996:

235-236) Hundreds of civilians were whipped, and more than a few were publicly executed. They slaughtered part of the Tuaregs' and other tribes' sheep, which enraged northern Arabs against them and led to the escalation of the conflict. During the conflict, 6-8000 people lost their lives. (Humpreys, Mohamed, 2003: 3-4, 19-21) Finally the government realized that they cannot eliminate the uprising by themselves, with their own armed forces, therefore, with the help of neighboring Algerian intermediation, the opposition parties sat down at the negotiation table and, on 1991 January $6^{\text {th }}$, they concluded their first peace treaty - Accord de Tamanrasset, it resulted in the immediate cessation of hostilities. 
(Bondersholt, Gylden- holm, 2012: 40); (Ilahiane, 2006: 119) The main points of the agreement were as follows:

- Immediate ceasefire and exchange of prisoners of war;

- Tuareg rebels retreat to the tribal areas;

- To reduce the number of the government's armed forces in the northern territories especially in Kidal;

- The immediate termination of military governance, the introduction of civil adminis- tration;

- The immediate termination of particular military garrisons which pose a threat to Tu- aregs;

- Integration of Tuareg rebels into Mali's army, with proper conditions - rank, duty station, etc.;

- The decentralization of administration, providing more autonomy in local affairs;

- Increased financial resources and infrastructure development for the northern region.

Later however, they did not respect the agreement completely; only in part. (Lohman,

2011: 6-7); (Diallo, 2008: 49) A military putsch, led by Amound Toumani Touré, overthrew the former dictatorial regime on the $11^{\text {th }}$ of April 1991 and the Tuaregs concluded their sec- ond treaty - Pact National — with the new government led by Alpha Oumar Konaré which officially ended the rebellion. Those Tuaregs who accepted positions were integrated into the government's army or were allowed into public service. (Schraeder, 2011: 191-193) In April of 1993,610 former rebels joined the army, in 19961200 people — part of them joined the National Guard and the police as well — and 300 people also joined the paramilitary forces and 120 people the civil administration. (Keita, 1998: 33-34) With this agreement, however the government managed to disunite the Tuaregs who were unable to consistently act against the government, so enforcing the peace treaty was not without problems. ${ }^{10}$ (Humpreys, Mo- hamed, 2003: 22-29); (Keita, 1998: 8-9, 20) The atmosphere of mutual distrust remained

10 Signing of the accord did not automatically bring peace between former enemies, who considered each other to be suspicious, and occasionally provoked bloody clashes with each other. This was the case in May $20^{\text {th }}$

1991 when one unit of the army was chasing Tuareg rebels and captured 48 Tuareg and Arab traders, and

the village leaders in Lere town and immediately executed them as anti-government rebels. The government tacitly supported - or just did not take notice of them - the tribal militias that initiated revenge on the Tuaregs who were terrorizing them before (who took "tax" from the farmers, and launched slave-hunting expeditions against them, etc.). The Songhai group established the Ganda Koi (the land owners) militia, who started exterminating farmer and shepherd Tuaregs who were not involved in armed clashes. There was a clash

among the Africans where a well-known religious leader and 60 of his followers were killed at the same time! Arab groups fought on the side of the Tuaregs, while on the side of the Songhais the Africa (Fulani / Peul) groups fought, supported by the government with soldiers and arms. Years of armed conflict have had an impact on the current conflict.

BESENYÖ János: War at the Background of Europe: The Crisis of Mali

and due to various misunderstandings the Tuaregs and the military repeatedly clashed with each other. For example, in 1994, part of the Tuaregs integrated into the Tonka and Kharous army garrison mutinied, which resulted in many losses of soldiers' lives. (Keita, 1998: 21) Therefore, some Tuareg groups established the Azawad People's Movement (Mouvement Populaire de l'Azawad - MPA), the Popular Front Azawad Liberation (Front Populaire pour la Libération de l'Azawad - FPLA), followed by the Revolutionary Army the Liberation of Azawad (Armée Révolutionnaire pour le Libération de l'Azawad - ARLA) organizations, which continued the battle against the government and other tribal groups. (Schraeder, 2011:

190) This period lasted until 1996, when the third treaty - Flamme de la Paix - was con- cluded on March $27^{\text {th }}$, after which, the opposing parties actually ceased hostilities. After the signing ceremony in the presence of the country's president Alpha Oumar Konaré, and the President of Ghana, the former rebels burned 3000 arms as a sign of confidence. (Bonder- sholt, Gyldenholm, 2012: 48); (Keita, 1998: 18) By this time the UN Refugee Agency had resettled those Tuaregs back into Mali who had fled from the fights and droughts to refugee camps in Mauritania. The government started investing into the infrastructure in the North

- construction of schools, health care facilities, and drilling wells - and began to provide greater autonomy for the Tuaregs, who now were able to join the political life of the country.

This period came to an end soon since the military putsch led by Amound Toumani Touré removed Konaré from his office in 2002. He was the one looking for peace at any price with the Tuaregs. For the new government the observation of the previous agreement with the Tu- arges became less important, so again they were marginalized. In the fight against terrorism, which followed 9/11, Mali, as a U.S. ally, announced a fight against terrorist organizations operating in the

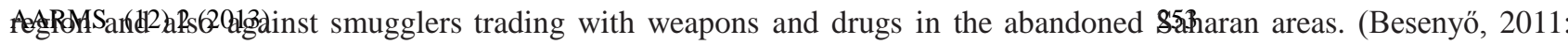
38-41) The Tuaregs who are familiar with the deserts played a significant role in these activities; therefore, the government forces launched several military operations against them which caused part of them to join Al-Qaeda. (Lecocq, Schrijver, 2007: 158-160); (Diarra, 2012: 7-8); (Besenyö, 2010: 148-154) The pro- liferation of light weaponry caused frequent armed clashes between the Tuaregs and their neighbors, which have gotten bloodier over time. Despite this, the government did not pay sufficient attention to the region. Therefore, the fights escalated in 2006, when more Tuareg leaders belonging to the Kel Adagh tribe deserted from the army and attacked Kidal and Meneka on May $23^{\text {rd }}$. (Lecocq, Schrijver, 2007: 155-156) That day, the rebels established the Democratic Alliance for Change (Alliance Démocratique pour le Changement du 23 to- day's-ADC) organization which demanded the developments of the northern areas and the implementation of the treaty signed in 1992. The Tuaregs moved themselves into the hardly accessible Tigharghar Mountains where the government powers were unable to liquidate their armed groups. Mali again requested the mediation of neighboring Algeria, hence July

$4^{\text {th }} 2006$ they brought the $4^{\text {th }}$ peace treaty - Accord d'Algers - under the roof, which was nothing else than the 
renewed version of the previous one. (Boukhars, 2012: 11) Similarly, they pledged the development of the northern regions, the integration of Tuareg soldiers into the national army, and the withdrawal of the government forces to their southern positions. However, part of the rebels did not believe the government and, with the leadership of Agh- ali Alambo and Ibrahím Ag Bahanga, they established the Tuareg Alliance for Change of Northern Mali - ATNMC organization, which continued the fight. Since the government did not have sufficient military force to crush the rebellion, they initiated peace talks again. They

\section{BESENYÖ János: War at the Background of Europe: The Crisis of Mali}

concluded the $5^{\text {th }}$ peace treaty in Kidal in April of 2009, which contained the implementation of the promises from the previous four agreements. (Bondersholt, Gyldenholm, 2012: 56)

It seemed that the government finally kept its promise. By December 2010 the army significantly reduced its station in the north and also set up a special Tuareg force unit. To demonstrate their peaceful intensions, they permitted the return of the Tuareg leader Ibrahim Ag Bahanga who was exiled in Libya for more than 2 years. In August 2011, the govern- ment approved a USD 65 million program for development of the northern regions. ${ }^{11}$ The amount that was necessary for the program was provided by the European Union, the World Bank, the United Nations Development Program and other donor organizations. However, no significant changes occurred in the North, smaller armed clashes continued to take place between the government and the Tuaregs when the government ordered new military units into the northern regions. (Bertelsmann Stiftung, 2012: 6, 21, 35) These conflicts had not yet reached the stimulus threshold to call the attention of the international community to deal with it. It should be recognized that not one agreement has been able to eliminate the mar- ginalization and segregation of the Tuaregs and have been unable to integrate them into their society. Time was just preparation for the next revolt to break out.

\section{The Eruption of the 2012 Uprising}

This low intensity conflict escalated on January $17^{\text {th }}$ 2012, when the National Movement for the Liberation of Azawad / MNLA $^{12}$ occupied the Aguelhok (Menaka) settlement and launched a comprehensive attack on the government forces stationed in the north. The mili- tary putsch, one month prior to the election, helped the attack and facilitated the disintegra- tion of the poorly equipped, unpaid military units fighting against the Tuaregs. It also helped in the disintegration of the functioning government. (Besenyő, 2012: 10-12) It started from the Kati barracks, led by Captain Amadou Haya Sanogo, and the putschists established the National Committee for Reconstruction, Democracy and Restoration of Statehood (Comite National pour le Redressement, la Democratie, et la Restauration de l'Etat CNRDR) organization. The putschists led by Sanogos, rebelled primarily because of the military lead- ership's inertia, and because of the captured and massacred soldiers (Diarra, 2012: 4) in the north garrison in Aguelhok, and against the corruption that runs across the leadership of the

11 Programme Spéciale pour la Paix, la Sécurité et le Dévelopement au Nord-Mali

12 The organization was formed in late 2011, mainly from the Movement of National Azawad-MNA which gave it its base, it was previously created in 2010 and was created based on a number of smaller and larger Tuareg groups. The MNA acted as a defender of the interests of the Tuaregs, but their main activities were limited to taking possession of international aid, and its lucrative smuggling with AQIM groups. Once the previously chased off people returned to Mali from Libya, the MNA merged into the MNLA organization. The new formation is extremely fragmented, with several types of ideology, conflict of interest and tension between each other, which were only temporarily set aside, because of the common enemy. They mainly owed the quick military victory to Mali's army units which were stationed in the north, because they did not have the proper weapons, training, and management and they had not been paid for months. The officers were involved in politics rather than in training or management. A large part of their activities involved corruption and smuggling activities. The MNLA were aware of their weakness and formed alliances with radical Islamist groups, which only used them for their own purposes. Currently they are at war with their former Islamist allies. The best known commanders are Muhamad Ag Najim and Algabassn Ag Intallah. According to their own claim they have 10,000 armed men, but many of these switched to the fundamentalist groups, or operate independently.

BESENYÖ János: War at the Background of Europe: The Crisis of Mali

country infecting the political elite and also evidenced through their nepotism. ${ }^{13}$ (Boukhars,

254 2: 5) Though the committee suspended the constitution, the rebels disorganization and other opposition, such as the lack of support from the majority of the population and from part of the army. ${ }^{14}$ The social dialogue they started dismally failed and the army has been forced to give up even more territory. The military takeover was not recognized by the international community, it not only protested against it but, also threatened the putschists with possible sanctions and military intervention. The African Union suspended Mali's membership and the representatives of the Economic Community of West African States placed further pressure on the leaders of the putsch to hand over the power to a civil governmental administration to govern the country until a new parliamentary election was held. By coercion they were forced to accept this. All participants in the putsch were given amnesty and Amadou Toumani Touré and Sanogo resigned from power and withdrew from public life. The former spokesman of the parliament, Diouncounda Traoré, was elected as the new president. However, the new government that stepped into of- fice in August 2012, did not win the total support of the society and also between the military and civil administration the atmosphere remained tense. (Boukhars, 2012: 7)

In early April, various groups, MNLA, the Islamist Ansar Dine (Defenders of the Faith) group ${ }^{15}$ as well as other 
Arab militias, launched an armed attack against the government. They occupied the three northern regions of Kidal, Gao and Timbuktu. On April $5^{\text {th }} 2012$ the Tuaregs occupied Douentza city. The next day, they announced that they had reached their objectives and declared the Azawad Republic. They formed their government, which has not been recognized by the international community. ${ }^{16}$

Gunmen involved in the fighting have been fighting previously in, the since fallen Libyan President's, Gaddafi's mercenary army. In late 2011 they fled to Mali along with their armed

13 http://www.jamestown.org/uploads/media/TM_010_Issue13.pdf (downloaded: 1401 2013)

14 Many units of the military did not support the putschists, for example the armed groups loyal to the former president tried to recapture the capital from the rebel soldiers, but their attempt failed.

15 The organization's first leader the Tuareg Iyad ag Ghali from the Ifoghas tribe, is considered one of the noblest among them. He is known for his conservative view of Salafisim (a follower of the Tablighi school) and is one of the emblematic figures of the 1990 revolt. He participated in the funding of the MNLA in late 2011, but the position he intended to get - because of his "suspicious" connections to Al-Qaeda, Algeria and Mali's political elite - he did not attain. According to his critics he did not want an independent state in the area of North, rather a state ruled by the law of sharia, which was opposed by most of the Tuareg who wanted to form a secular government and legal systems. Therefore, when the Tuaregs launched an attack against the centra government, they set up their own group, Ansar Dine, which received logistical and military support from the Katiba Abdelkrim al-Ansar (winners battalion) militia led by Targum. Their estimated number could be around 500-2000 people, among them foreign (Yemeni, Qatari, Algerian, and Nigerian) armed men could be found. The group's first success was the occupation of the city of Kidal, and then the expelling of the MNLA from Timbuktu. Since the uprising in April 2012 was led by him, it made him seem the most successful military leader, in addtion he has the best trained and equipped armed men. However, the majority of Tuaregs still do not accept him as the leader. http://www.bbc.co.uk/news/world-africa-18814291 (downloaded: 03012013 ) 16 The original declaration could be found: http://www.mnlamov.net/component/content/article/169-declarationdindependance-de-lazawad.html (downloaded: 1601 2013)

BESENYÖ János: War at the Background of Europe: The Crisis of Mali

inventory and battle experience ${ }^{17}$ (Besenyö, Marsai, 2012: 92-93); (Diarra, 2012: 12-13) where they almost immediately launched an attack against the secular government. ${ }^{18}$ (Inter- national Crisis Group, 2012: 3); (Humpreys, Mohamed, 2003: 18-19); (Keita 1998: 13-14) These groups temporarily allied against the government forces and even collaborated with the local branch of Al-Qaeda - AQIM / Al-Qaeda in the Maghreb - as well. ${ }^{19}$ (Diarra, 2012:

13-15) However, this alliance was vulnerable since the Tuaregs desired their own "secular" state; on the other hand, the Islamists imagined a country based on religion, applying Sharia laws, as their future. ${ }^{20}$ They started introducing this in those territories where they gained power; where they destroyed hotels and restaurants - because they sold alcohol previously

- and they also mutilated more people because of various "offenses". The Tuaregs did not agree with these extremist kinds of outbursts, but the Islamist organizations such as Ansar Dine, the Movement for Unity and for the Jihad for Western Africa (MUJAO - Le Mouve- ment pour l'unicité et le jihad en Afrique de l'Ouest) ${ }^{21}$ and the Nigerian Boko Haram, who are present here, had more armed men and power than the Tuaregs. ${ }^{22}$ Therefore, at first they tried to put aside their differences and tried to gain control with joined forces of those terri- tories which have fallen under their rule. For example, the Islamist groups appointed Emir Yahya Abou al-Hammam as the leader of the occupied Timbuktu, someone who belongs to

17 Unfortunately Libya's NATO operation contributed to this, in which the air strikes eliminated the Gaddafi forces, but could not prevent the dictator's army, Mali's Tuaregs (their estimated number 2000-4000), equipped with huge amounts of light and heavy weaponry from returning to their home countries, where they might use this against French and other European soldiers. Thousands of SA-7 anti-aircraft missiles are believed to be in their hands, which have not been used yet. Of course, the government of Mali also made a mistake, when they let the Tuaregs return to the country without first taking care of their weaponry disarmament and demobilization.

18 Part of the weapons after the 1963 uprising, while others during the great drought started in 1984 migrated from Libya, where they entered the

256 Pan-African forces which were founded by Gaddafi in 1972. The squad gained considefablecombatexperience in Afghanistan, Lebanon, Israel (Palestinian intifada), Syria and Chad.

19 The Salafist Group for Preaching and Combat (GSPC) is considered the predecessor group, which in 2007 became an African ally with AlQaeda. The organization has been embedded into the society of the northern areas by 2003, where they gained considerable political and social support and therefore they were able to reinforce the organization shattered by the Algerian security forces. Their best known leader is Abdelmalek Droukdel. In recent years it has become one of the most structured and supported terror groups in Africa. Their incomes are from smuggling cigarettes, alcohol, drugs, weapons, and other goods, as well as from taking hostages. The AQIM takes advantage of their Arabic roots and enjoys more support from the Arab

community. One of their central powers is Timbuktu where they cooperate closely with the local Arab militias which were sponsored and supported by former president - Toure. The inter-ethnic conflicts between Arab- Tuareg and Fulani Song Hai (Peuhl) makes the organization's activities substantially easier. In addition, the income earned by AQIM were used to bribe and purchase the tribal leaders - with Sport Utility Vehicles, weapons, etc.. - they then provided free access throughout their lands, occasionally information and logistical support for the organization's soldiers. The AQIM units have a significant number of well-trained experienced foreign armed men from Iraq, Afghanistan, Yemen, Algeria, etc, who unlike the Tuaregs and Arabs living in Mali, have nothing to lose, therefore reaching an agreement with them is almost impossible.

20 http://www.al-monitor.com/pulse/security/01/08/torture-and-violence-against-opp.html 
21 The MUJAO spun off from AQIM and first entered the scene in the occupation of Gao city, although according to some information at the end of 2011, their men kidnapped three aid workers from the Algerian Tindouf refugee camp. The organization's members are not Tuaregs, but are assembled from Lamhar and Songhai tribes who, although deeply religious, still obtain cover for their expenses from crimes committed. They maintian good relations especially with the Arab community, most of their leaders are from Algeria and Mauritania. They are able to finance their activities better than the MNLA. They have about several hundred armed men and their most important leader is Bilal Hicham.

22 http://www.fas.org/sgp/crs/row/R42664.pdf (downloaded: 1701 2013)

BESENYÖ János: War at the Background of Europe: The Crisis of Mali

Al-Qaeda. But not much later, the news went around that the city was divided between the Is- lamists and the Tuaregs, and occasionally armed conflicts took place. Similar cases had been happening in other places which soon caused the momentary allies to jump at each other's throats. On June $27^{\text {th }}$ in the city of Goa MUJAO, militants launched an attack against MNLA and occupied its headquarters. Soon after, they were chased out of the city. The intensity of the battle was typified in that clash where the Tuareg leader, Bilal Ag Acherif, was wounded and lost nearly 20 of his armed men. ${ }^{23}$ By the end of July, the MNLA lost almost all of their influence in the northern territories where Islamist groups gained power.

It seems there is no unity among the Tuaregs, which was proven on May $19^{\text {th }}, 2012$ when, the forces wishing to preserve the country's unity, established the so called Republic Movement for Reconstruction of the Azawad (Mouvement républicain pour la reconstruction de l'Azaouad - MRRA) organization, whose army not only launched an attack against the Islamic groups but also against the MNLA. Not so much later, the former members of the Arab community, the National Front of Liberation of Azawad was established; their members want peace in Mali and are ready to confront any armed groups initiating the disruption of the country. (Besenyő, 2012: 10) Similarly, the group, Front for the Liberation of the Azawad (FPA), split from the MNLA and no longer have independence but a crackdown on Islamist extremism as its most important priority. ${ }^{24}$ Other ethnic groups living in the north - and in some places, the settlements themselves - similarly created their own militias with elaborate names like Patriotic Resistance Movement for the Liberation of Timbuktu (patriotique the Mouvement pour la Libération de résistance de Tombouctou - MPRLT), but their effective- ness is questionable. Using government subsidies, they established 15 militias of which the best known are the Patriotic Resistance Forces, (Forces patriotiques de résistance - FPR) including 6 armed groups and 6000 members and the North Mali Liberation Front, (Front de Libération du Nord-Mali - FLNM) which includes two Hai Song groups and a couple hundred militants controlled by a Tuareg colonel from the army. (ACAPS, 2012) It seems in the north, everyone is fighting each other — even occasionally militant Islamist forces — but no one is strong enough to be able to impose their will on other groups.

\section{The Humanitarian Situation}

After the rebellion broke out in January of 2012, within 3 weeks, more than 30,000 people fled from their residences, soon followed by tens of thousands of others. A majority stayed in government controlled areas - mainly in Bamako and surrounding areas - and the minority moved to the neighboring countries of Mauritania, Burkina Faso, Niger, Guinea, Togo and Algeria, where they quickly set up refugee camps. Several thousand people remained in the North hiding in abandoned places, too afraid to leave their small assets behind. These people were not only exposed to nature, but to armed Islamists as well, bent on robbing, beating and raping them. Many were murdered trying to protect themselves and their families. ${ }^{25}$

More charges were drawn up by the Human Rights Watch organization's fact revealing team, reporting from the scene on the various groups occupying the northern territories, they

23 http://www.bbc.co.uk/news/world-africa-18610618 (downloaded: 1401 2013)

$24 \mathrm{http} / / /$ bigstory.ap.org/article/ap-interview-malis-secular-rebels-splinter (download: 1401 2013)

25 http://www.jamestown.org/uploads/media/TM_010_Issue13.pdf (downloaded: 1401 2013) and http://www.unhcr.org/refworld/pdfid/505c16fe2.pdf (downloaded: 1401 2013)

BESENYÖ János: War at the Background of Europe: The Crisis of Mali

caAled attention to the terrorizing of civil society, raping of women and young girls, robbing, looting, brutalizing captured government soldiers, and the use of child soldiers (in the pur- suance of war, Ansar Dine recruited children by force into their units). ${ }^{26}$ There is evidence that Tuareg and Islamist groups destroyed Christian churches, bible schools, hospitals, and attacked Christian minority groups living in the country. As such, a mass exodus began. Most of the Christians living in the north fled to government controlled territories or to one of the neighboring countries. The Islamists however did not spare the Muslim shrines either; such as the one located in Timbuktu - one of the World Heritage Sites - a grave considered holy by Muslim religious teachers was partly destroyed along with the 600 year old entrance of the Sidi Jahya mosque. ${ }^{27}$ The introduction of Islamist rule not only destabilized public law and order, but the accompanying executions, stonings, limb mutilations, tortures and public flogging also caused more refugees.

Of course, we can not call the government forces fighters for the truth either, as they exe- cuted Tuareg policemen and soldiers because they were afraid that they would betray them to the MNLA. (Besenyő, 2012: 11) In light of this, it is understandable that the majority of the survivors turned their backs on the government and joined the MNLA forces. 
Some members of the government forces also took part in the abuses, robberies and even murders of Tuaregs and other groups. $^{28}$

Since the outbrak of the conflict, more than 420000 people were forcibly displaced from their residences, their care remains unresolved. ${ }^{29} \mathrm{~A}$ part of the refugees remained in Mali, but even more people have been fleeing into neighboring countries, where they feel more secure. Out of the 3.3 million people living in the North, the supply of at least 1.76 million is not ensured, as access to food is increasingly more difficult with prices escalating astronomically since the outburst of the conflict. (ACAPS, 2012)

However, the Islamists banned any international aid organizations from conducting any hu- manitarian activities on territories controlled by them. Some of these organizations were even afraid to enter these territories for fear of kidnapping and other violent acts in which members of the Red Cross were harmed, causing the evacuation of the majority of their colleagues from Mali. The hostile behavior against foreigners has been significantly amplified by the ongoing operation of the French, therefore the aid workers are in actual danger in Mali and in neighboring countries. Since most public institutions (hospitals, clinics, schools) are not operational, and the majority of wells ruined, therefore health care has almost completely disappeared in the north. As a cholera epidemic broke out in Gao, the results worsened and the death toll rose higher.

\section{International Reactions}

Seeing the military success of Islamist expansion the African Union called upon the UN Secretary General to contribute with an UN Security Council resolution to establish a "West- African Afghanistan" before the immediate deployment of African troops. ${ }^{30}$ Representatives

26 http://www.hrw.org/node/106800 (downloaded: 04012013 )

27 http://hhk.uni-nke.hu/downloads/kozpontok/svkk/Elemzesek/2013/SVKK_Elemzesek_2013_1.pdf (downloaded: 24012013 )

28 http://reliefweb.int/sites/reliefweb.int/files/resources/afr370012012en.pdf (downloaded: 2001 2013)

29 http://www.fas.org/sgp/crs/row/R42664.pdf (downloaded: 1701 2013)

30 http://www.cbc.ca/news/world/story/2012/11/14/un-african-union-mali.html (downloaded: 14 01.2013)

BESENYÖ János: War at the Background of Europe: The Crisis of Mali

of the Economic Community of West African States held extraordinary meetings, where they agreed, if necessary, they would deploy organized forces - similarly as it was done in Lib- ya - to restore the legal order, prevent the country's collapse and provide humanitarian aid to Mali and the surrounding states. ${ }^{31}$ The leader of the regional organization, the Ivorian leader Alassane Ouattara, called the events that happened in Mali a serious security threat, not only for Mali but, for the entire region. The community leaders threatened the MNLA leaders during the Ouagadougou City meeting, that if they don't give up their secessionist aspirations, then they will send significant military units to support the government forces to recapture the northern territories. The threat was effective to some extent as the Tuaregs' fight with Salafist groups wore away at their demands for independence; weakening it significantly and culminating in their agreement to begin negotiations with the government. The Tuaregs even offered to help in operations against Ansar Dine and other Salafist groups. Nowadays it seems that they would even give up their aspirations for independence. ${ }^{32}$ Meanwhile, the Economic Community of the West African States made agreements with leaders of neigh- boring countries outside of the negotiations and imposed economic sanctions and embargos against Mali. So previously imported products became no longer available for purchase. The organization and the African Union asked for the intervention of the UN and sought to obtain authorization to launch armed interventions against the Islamists. The UN passed a positive judgment on this request and the Security Council on October $12^{\text {th }}$ of 2012 passed a resolution (2071) against the occupying Islamist forces in Mali. ${ }^{33}$ Representatives of the Eco- nomic Community of West African States agreed on November $11^{\text {th }} 2012$ in Nigeria to send troops with the support of the UN to recapture the northern territories occupied by Islamists. (ACAPS, 2012) This has not been easily realized, since the organization's first plan to launch a 3300 person military operation was rejected by the UN - they only approved planning, troop organization, preparation and equipment gathering. Because of the escalation of the conflict, the UN Security Council finally approved part of the resolution $208528 p_{3}$ December

$20^{\text {th }}, 2012$ to launch an African-led International Support Mission in Mali (AFISMA). An intervention mandate was for one year. (UN Security Council, 2012) Of course it is question- able what this mission can achieve, since the Economic Community of West African States already operates a military mission in the territory of Bissau-Guinea, where in April 2012 a military putsch happened. The Community has sent peacekeepers to the country to restore the civilian government, but the missions mandate was not clarified, and no results have been demonstrated. Therefore, it is questionable for many if the Community can play an effective role in Mali.

There was no consensus between the leaders of the neighboring countries. One of Alge- ria's (Diarra, 2012: 17-18) - the region's political and military great power - ministers stated that the conflict can only be handled by negotiation, and Mali can not be divided since they reasonably feared that if the Tuaregs establish an independent state then Tuaregs living 
31 http://www.jamestown.org/uploads/media/TM_010_Issue13.pdf (downloaded: 1401 2013)

32 If they took the offer seriously from the leaders of MNLA, the international community should accept it since the Tuaregs could be effectively used in the "enemy of my enemy is my friend" principle against their former allies, who would want revenge. The question is what do they want in return and also what is Mali willing to give since the independence of Azawad is out of the question, maybe a limited autonomy could be realized. http://www.bbc.co.uk/news/world-africa-21009958 (downloaded: 1401 2013)

33 http://www.un.org/News/Press/docs/2012/sc10789.doc.htm (downloaded: 1401 2013)

BESENYÖ János: War at the Background of Europe: The Crisis of Mali

in Algeria will step forward with similar claims. ${ }^{34}$ In the recent past Algeria closed its border with Mali, so as to prevent the flow of militants and various arms, and thereafter in Operation Serval closed its airspace against French aircraft. Many considered that these steps were nec- essary, but insufficient, and they urged for an increased role of the region's leading countries in the conflict. (Boukhars, 2012: 13-17) Burkina Faso was also supportive of the negotiated settlement, also in the region the president Blaise Compaore is known as the "peacemaker" for his mediation role between the Community of West African States and the various power groups in Mali. ${ }^{35}$ However Niger clearly supported swift and decisive military action. The country's foreign minister demanded the immediate abolition of northern Mali's "terrorist groups" at a conference in Nouakchott organized by the neighboring states and later Presi- dent Mahamadou Issoufou himself claimed that armed Islamist are being trained by Afghan and Palestinian jihadists. Ivory Coast not only strengthened their borders but also allowed French military units to pass through to move against the extremists. These units launched "Operation Licorne" in September of 2002 from Ivory Coast to help the UN mission. ${ }^{36}$ Sen- egal and Ghana, however, strongly rejected any participation in military operations in Mali. (Boukhars, 2012: 18) Finally, after several debates and discussions, the surrounding coun- tries consistently agreed to support the World Organization's military intervention which aims to restore the integrity of Mali.

Since 2002, the United States has been co-operating with the government on the "Pan Sahel Initiative" and its successor, the Trans Sahara Counter-Terrorism Partnership (TSCTP) anti-terrorism program (Lecocq, Schrijver, 2007: 143-145); (Diarra, 2012: 20) as its most important partner in the region the US hopes to make Mali into an example of African de- mocratization, despite initially expressing concerns regarding the conflict. At this time they did not want to admit that their policies in the Sahel countries have failed, because in all three countries they supported (Mali, Mauritania and Niger), military putsches occurred in recent years. Initially designed military intervention never took place because of the high risk involved. ${ }^{37}$ Sometime later they joined the Economic Community of West African States-led negotiations, provided substantial humanitarian aid for the refugees, but still argued against military intervention. ${ }^{38}$ At the same time they provided substantially increased military and training support subsidies for the anti-terrorism fight. Finally, the AQIM and other militant Islamist groups gained strength causing the USA to consider Islamist military groups as glob- al threats instead of regional ones and to take a limited role in the operations against them. In this framework they provided logistics, military reconnaissance and military intelligence data for the surrounding countries, and initiated operations although they have not been willing to send troops. ${ }^{39}$

After the proclamation of the breakaway Tuareg state the European Union indicated that it does not support any action which leads to a disintegration of Mali, and approved a plan in which they provide training and logistic support within a framework of a limited military

34 According to some information the MNLA has good connections with the opposition Berber party in Algeria which worries many.

35 http://www.jamestown.org/uploads/media/TM_010_Issue13.pdf (downloaded: 1401 2013)

36 http://www.guardian.co.uk/world/2013/jan/15/french-troops-triple-mali (downloaded: 2001 2013)

$37 \mathrm{http} / /$ www.guardian.co.uk/commentisfree/2013/jan/14/france-lonely-intervention-mali (downloaded: 0120 2013)

38 http://www.fas.org/sgp/crs/row/R42664.pdf (downloaded: 1701 2013)

39 http://www.guardian.co.uk/world/2013/jan/15/mali-who-is-doing-what (downloaded: 0120 2013)

BESENYÖ János: War at the Background of Europe: The Crisis of Mali

operation for the government forces by European soldiers. According to some opinion this mission could begin in February.

As far as the country's former colonial keeper, France, was concerned, Mali was still in their sphere of interest despite initial hesitation to intervene in the conflict due to the lack of dexfsopment(2013)single solid point of view in the French government. ${ }^{40}$ They were only able to agree that they clearly reject the Tuaregs independence effort and support the unity of Mali. Then, after several months of debate the "hawks" prevailed and persuaded the French president Francois Hollande to launch a limited military operation "Operation Serval" against the Islamist forces. Ban Ki Mun, UN Secretary General, supported this operation from the beginning, and on December $20^{\text {th }} 2012$ the UN Security Council voted without dissent in the resolution 2085, so it opened the way for the intervention of the French. ${ }^{41}$

\section{The French Military Operations ${ }^{42}$}

The Islamists grew bored with the 2012 year-end stalemate and, in January of this year, they launched an armed intervention against the south-west part of Mali. Three militant groups with a total of 1200 armed men occupied Konna and Mopti cities, and posed a threat to the strategically important city of Sévaré. ${ }^{43}$ The country's demoralized army was unable to stop their push forward and, as a result, the alarmed government in Bamako called on the former colonial 
keeper, France for military intervention, and also declared a state of emergency on January $13^{\text {th }}$ of $2013 .{ }^{44}$

Subsequently, France launched the military operation known as "Operation Server" on January $11^{\text {th }} 2013$ to stop the attack, ensure the protection of the capital Bamako city, and to help to restore the country's unity. The operation, according to the commander Admiral Edouard Guillaud and to French official statements, will only last till the arriving AFISMA

40 They could not agree in regards to the intervention because 8 French hostages are still in the hands of the terrorists, and they were threatened with execution if the military operations were launched. The operation was partly compelled by the fact that 6000 French citizens live in Mali, and in the surrounding Muslim states another 30000 reside. These are the main target for the Islamic extremists. The French government mainly worries about their protection.

41 Romano Prodi was appointed by the Secretary as the Special Rapporteur on the Sahara crisis, which indicates that the United Nations would take a major role in consolidating Mali's region after the military operations. However, there are those who believe that Prodi is not the right choice, as he does not know the Sahel countries, nor does he speak French. This will significantly reduce the efficiency of his work. http://www.guardian.co.uk/world/2013/jan/15/mali-france-military-intervention (downloaded: 20012013 )

42 The operation day by day can be reached in this page: http://news.silobreaker.com/operation- serval-11_533259771 and also at http://www.armyrecognition.com/serval_opertaion_mali_french_army/ index.php link (downloaded: from 12012013 continuously)

43 This is the only city beside Bamako which is able to land heavy cargo aircraft, which are required for the effective management of the humanitarian situation in the North, or it could even provide a support operation to compel peace.

44 http://www.sldinfo.com/the-french-serval-operation-the-double-edged-sword-of-the-mali-operation/ (downloaded: 17 01 2013)

BESENYÖ János: War at the Background of Europe: The Crisis of Mali

troops will be able to take effective action against the extremists. ${ }^{45}$ The question is what if the Africans fail in Mali, similarly to Burundi and Darfur. Will the French remain in Mali or will they entrust the fate of Mali to the African's good luck. They will likely remain as it was probably already decided in early January to intervene. The fact made it easier that although they did not have any units in Mali, but in the surrounding states nearly 3,500 soldiers were stationed accordingly to various inter-state agreements. (Besenyő, Hetényi, 2011: 199-208) The first attack against the extremists was launched by the $4^{\text {th }}$ helicopter regiment and was carried out by "SA340 Gazelle" type attack helicopters in Sevan region where an armed mili- tary convoy was stopped. In this action the French suffered their first combat loss when Lieutenant Boiteux Damien helicopter pilot lost his life. The next day, several hundred French soldiers took part along with

a Malian army unit in the attack against the Islamists who had occupied Konna city a couple of days prior and where they liquidated one of Ansar Dine's command posts. The news coverage reported falsely that time that the city had been recap- tured since the disorganized, poorly equipped and trained Malian army was unable to take advantage of the

French air strike's benefits. The government finally gained control over the city on January $18^{\text {th }}$. On the same day, French fighter jets bombed Douentza, Lere, Gao and Kidal cities, where they destroyed fighting positions and logistic storage areas (fuel and weapons). In this operation the French used the double-action (laser / GPS) GBU-49 preci- sion bombs for the first time. The helicopters and fighter jets involved in the operation came from the French military base in Chad or Burkina Faso. In the first two days of "Operation Serval" at least 100 people lost their life from the radical group while only a couple of people from the French-Malian units. ${ }^{46}$ The radical groups launched a counterattack toward Bamako

and occupied Diabaly city, but due to the increased French air strike they began their retreat not only from the central areas, but they also withdrew from Gao, Kidal and Timbuktu cities. Nevertheless, the French have become more cautious, as they were surprised by the trained

Islamists groups, using modern arms, organization and determination.

This caution did not hurt since the different armed groups liked to hide among the civil- ian population, whom they use as shields during the attacks making it very difficult to dif- ferentiate fighters from civilians leading to more civilian deaths during the fights. ${ }^{47}$ Never- theless, the French advance continued without hindrance, and on January $16^{\text {th }}$ they attacked

AARMS (12) 2 (2013)

45 From the French military force the following units engaged in operations: French Foreign Legion $1^{\text {st }}$ regiment

(1er Regiment de Cavalerie étranger), $2^{\text {nd }}$ Marine Regiment (2e Regiment d'Infanterie de Marine), 21 ${ }^{\text {st }}$ Marine Regiment (21e Regiment d'Infanterie de Marine), $3^{\text {rd }}$ Parachute Regiment (3 e Regiment d'Infanterie de Marine de Parachutistes), $92^{\text {nd }}$ mechanized infantry regiment of the French Special Forces (Brigade des Forces spéciales Terre, BFST), and the 4th Special Force Helicopter regiment (4e Regiment d'Helicopteres des Forces spéciales). The planned maximum number of troops will be 2,500. This number, however, on

$21^{\text {st }}$ of January increased to 3150, from which 1600 stayed in Mali. In the air strike two Mirage F1 CR and six Mirage 2000 D 4 (Chad), the 1/7es Provence fighter century Rafale fighter aircraft (France), two C135 transport aircraft and several reconnaissance aircraft and combat helicopters century (Tiger EC 665 attack helicopter with) were involved. Read more about the air force:

http://theaviationist.com/2013/01/24/mali- air-war-update/ (downloaded: 2401 2013) The ongoing operations were led by Brigadier General Bernard Barrera in Mali. The allies estimate approx. 3000 extremists in oppositions, since some of them have already fled to neighboring countries, and also approx. 3000 MNLA militants are not fighting against the French.

46 http://www.bbc.co.uk/news/world-europe-21002918 and http://www.guardian.co.uk/world/2013/jan/15/mali- france-military-intervention (downloaded: 20012013 )

47 http://www.guardian.co.uk/world/2013/jan/16/french-ground-operations-mali-underway 
and recaptured Markala first and on January $21^{\text {st }}$ Diabaly and Douentza cities. ${ }^{48}$ At the same time the French reached Niono and Sevan towns and continued the air strikes, in which the fleeing Islamist from their position in Kidal lost several of their vehicles. On January $25^{\text {th }}$ the air strikes continued in the area of Asongo and Hombori, and not long after the French- Malian units attacked Gao city. On January $26^{\text {th }}$, the French special units occupied Gao's strategically important positions (airport, Wabary bridge) and the entire city was recaptured a few hours later. Meanwhile from Diabaly toward Lere and Timbuktu the French launched a 600 person unit, which the Islamists tried to stop with smaller ambushes. Almost imme- diately after replacing Gao's occupying unit with the $21^{\text {st }}$ Marine regiment as their counter- part, they advanced toward Timbuktu, whose extremist occupiers had retreated by January

$28^{\text {th }}$. On the same day, the MNLA militants occupied Kidal, Tessalit and Khalil settlements which had been left to their fate previously by the Ansar Dine militants. The French troops reached their last base Kidal city on the night of January $29^{\text {th }}$ which was occupied without a fight. ${ }^{49}$ After that, the extremists who stayed alive tried to flee into their hiding positions in the desert or tried to flee to the surrounding countries. In the next period if the French and their Allies want to completely liquidate the extremist groups and prevent them from seeping back to Mali after the departure of the French, then possible desert operations need to be prepared where their air and technical advancement prevails less. This is clearly not a very appealing prospect as the French political and military leaders intend to minimize the loss of manpower. Taking the radicals' fighting experience and equipment into account, this will not be an easy task.

The U.S. took part in the French operation with logistic and intelligence support, with C-17 military transport aircraft operating an air bridge between France and Bamako, and also providing information gathered by satellites and drones. Further military contributions were the U.K. contributing, 2pcs C-17 Globemaster III transport aircraft, trainers and con- sultants, a special unit and reconnaissance aircrafts, while Canada provided C-17ER Globe- master III military transport aircraft), Germany 2 pcs. Transall C-160 transport aircraft, Italy

2 C-130 Hercules and Boeing KC-767, the United Arab Emirates 2pcs C-17 Globemaster III transport aircraft, Spain C-130 Hercules transport aircraft, Belgium C-130 transport air- craft and an Agusta 109 paramedic-rescue helicopter, Sweden C-17 Globemaster III trans- port aircraft and Denmark C-130J-30 Super Hercules transport aircraft providing logistical support. The French have had multiple negotiations with several other European countries for operational support which they have ultimately not realized..$^{50}$ Interestingly those states - Italy, Spain -, which are major final destinations for drugs and illegal immigrations through Mali, did not participate in the military operations, and respectively, their participation in

\footnotetext{
48 http://www.expatica.com/fr/news/french-news/two-weeks-of-french-intervention-in-mali_256661.html (downloaded: 24012013 )

49 http://www.bbc.co.uk/news/world-africa-21256781 (downloaded: 3001 2013)

50 Unconfirmed information indicates that Hungary offered a maximum 10 person medical team to serve in the operation. The French took notice of it but have not officially requested the units deployment.
}

BESENYÖ János: War at the Background of Europe: The Crisis of Mali

support was not substantial. ${ }^{51}$

Most of the international community considered it necessary and accepted the military intervention, but a good few of them opposed it, talking about French re-colonization of the country. This is contradicted by the fact that the majority if the population of Mali gladly welcomed the French soldiers, whom they had been waiting for, to help the removal of

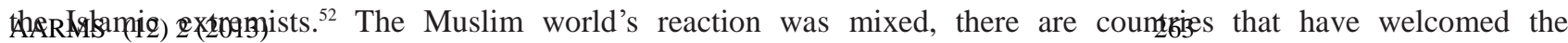
intervention, and have supported it, such as the United Arab Emirates, but many protested against the "crusaders", and demanded their immediate withdrawal from Mali. On January $16^{\text {th }}$ a group of AQIM occupied the Amenas gas field in Algeria, and took

41 foreign hostages of whom 37 died during this Algerian hostage situation. Although the AQIM leader Mokhtar Belmokhtar stated that the action was a response to the French in- tervention in Mali, many signs indicated that it was planned before that. Nevertheless, all States involved in the military operations should prepare for possible terrorist attacks. At the Arab Economic Summit in Saudi Arabia on January $21^{\text {st }}$ the Egyptian President Morszi in a strongly worded statement condemned the French intervention, which, according to him, poses threats to the neighboring states. So far these opinions were not able to seriously effect the Server Operation in which the French have been demonstrating considerable profession- alism with minimal loss. However the peacemaking process has been traduced by war crimes committed by Malian soldiers who have been executing Islamic extremist without evidence or trial. ${ }^{53}$ 


\section{The Operation Launched by the United Nations}

In this operation, the African States offered 3,500 soldiers, and financial, logistical and intel- ligence support is expected from the West (European) states. According to the World Organi- zation's plan, the troops will arrive in September of this year but the international community is applying increased pressure on the African states to start the operations as soon as possi- ble. ${ }^{54}$ The operational leader Nigeria however indicated that even if the African teams arrive prior to Mali, their training and installment would take considerable time, so they would not

51 In my opinion more incorrect beliefs appeared in connection with the operation. One interesting example was Anne Applebaum's recent writing (The world's new super power, http://fullcomment.nationalpost. com/2013/01/28/anne-applebaum-on-europe-the-worlds-newsuperpower/ (downloaded: 2901 2013). She writes about Operation Serval as the European superpower's successful military action. However, if we take into account the EU's military and peacekeeping operations up to date, then we can clearly see that a significant part of the European countries have limited ability to participate in any operation. Some places the military capability is there, but the policy makers do not support "expensive foreign adventures," but even more of them are countries who can not afford a long-term foreign military action, not even as part of an alliance. We must clearly state that the operation in Mali is a purely French military operation (the Mali army units are demoralized and their force value is highly questionable, the African soldiers have not been previously involved in live deployment), even with the limited support provided by the U.S. and some European countries. This evidenced is supported by the fact that the French did not ask for NATO support

in any action when it was initiated nor during its progress. The training operation which is to be launched in February by Europeans (EUTM MALI), even if it achieved important goals, will not contribute to the success of the current operations and their results will be visible at a later time.

52 http://hhk.uni-nke.hu/downloads/kozpontok/svkk/Elemzesek/2013/SVKK_Elemzesek_2013_1.pdf and also http://www.aljazeera.com/indepth/interactive/2013/01/201312113451635182.html (downloaded: 2401 2013)

53 http://edition.cnn.com/2013/01/24/world/africa/mali-military-offensive/index.html?hpt=hp_t3 (downloaded: 25 01 2013)

54 http://www.guardian.co.uk/world/2013/jan/16/mali-guide-to-the-conflict (downloaded: 2001 2013)

BESENYÖ János: War at the Background of Europe: The Crisis of Mali

be ready for immediate deployment. Some have also questioned the African soldiers' effec- tiveness in the desert environment, as most come from the entirely different environment of rainforest and savannah, and are less familiar with desert tactics. ${ }^{55}$ We have not yet mentioned that the Islamists are equipped with better weapons than the African units, whose mandate is only for one year. The most highly skilled Nigerians have to realize that not everyone at home supports their role in Mali where the activities of Boko Haram are gaining strength. Because of internal security problems Nigeria may even order its soldiers back, but this could also happen in the case of other African countries. Perhaps this is also the reason why they tried to negotiate with the opposition partners, but at the end they could not avoid the military intervention. On January $18-19^{\text {th }}$ the first 260 African soldiers (Nigeria, Togo and Benin) arrived at Bamako, but they did not participate in the operations. According to the prelimi- nary agreements Chad $2000,{ }^{56} \mathrm{Nigeria}$ 1200, ${ }^{57}$ Togo 540, Niger 1200, Senegal and Burkina Faso 500 each, Benin 300, Guinea 150, Ghana 120 soldiers, were offered to the AFISMA unit established by the Economic Community of West African States. They appointed Major General Shehu Abdulkadir from Nigeria as the mission commander, Brigadier Garbo Yaya from Niger as the deputy and chief Jean Paul Ntab from Senegal as the colonel.

Inspired by the French success on January $19^{\text {th }}$ in Ivory Cost city a meeting was held by the leaders of the West African States, ${ }^{58}$ as well as Chad's President Idriss Deby, the French Foreign Minister Laurent Fabius, the representative of the U.S., the EU, Great Britain, Ger- many, Spain, Belgium, Burundi, Canada, Egypt, Italy, Libya, Mauritania, Morocco, South Africa, and Tunisia. The participants Côte d'Ivoire, Ghana, Liberia, Senegal and also Sierra Leone agreed to start assembling their troops in Mali. ${ }^{59}$

On January $21^{\text {st }}$ the Economic Community of West African State's spokesman Abdel Fatau Musah announced that the African troops will arrive by January $29^{\text {th }}$ and they will immediately begin to fight against the extremist groups. ${ }^{60}$ In the light of the former African operations, this statement seems a bit hopeful, especially if we consider the deficiency in the qualifications and equipment of the African troops. (Besenyö, 2008: 5-15) This was ev- idenced by the African Union executive meeting held on January $25^{\text {th }}$, in which the member states were repeatedly asked to send more troops as soon as possible to AFISIMA units. Also the member states requested immediate financial and logistical support from the World Orga- nization for the operation. However, the UN Secretary-General only supported this request if the mission's logistic supply is not provided by the organization rather, in a framework of bilateral agreements AARMS (12)2 (20.13) , the U.N. would only take over this activity in the stabilization period 265 fter all the military operations concluded. In fact, according to the secre-

55 http://www.guardian.co.uk/world/2013/jan/16/mali-french-ground-war (downloaded: 2001 2013) és http://www.issafrica.org/iss_today.php?ID=1558\%2634 (downloaded: 20012013 )

With these viewpoints I agree as well, I served as a military advisor in Darfur AMIS (African Union Mission in Sudan) in the peacekeeping mission in 2005 appointed by the European Union, where for the same reasons many soldiers lost their lives to the African troops in local armed groups' clashes.

56 Chad sent a 1200 soldier mechanized artillery regiment and two 400 capita logistics battalions into Mali, but not under African, but French command.

57 http://www.bbc.co.uk/news/world-africa-21121262 (downloaded: 2001 2013)

58 Benin, Burkina Faso, Côte d'Ivoire, Ghana, Guinea-Bissau, Liberia, Mali, Nigeria, Niger, Senegal and Sierra Leone

59 http://www.afriquejet.com/20130120227/Mali-intervention-force-ECOWAS-mobilises-more-troops-logistic- support.html (downloaded: 20 01 
tary-general of the World Organization the organization would be unable to perform its task if their employees became the target of AQIM and other terrorist organizations. ${ }^{61}$

In the meantime, the possibility was raised that the Chad and Niger units gathering in Niger could open another front in the back of the extremist group, but this failed when they destroyed the key bridge for the possible operation next to Tassiga which would have given easy access to Gao city for the Africans. The Chad and Niger units only arrived after the capture of the city, and they took over its supervision. On January $29^{\text {th }}$ the Chads occupied Menaka, while the Nigers Ansongo cities which are used as bases for further operations. The leaders of the Economic Community on 28 of January approved the increase of the number of per capita to 5700 to which Chad provided an additional 2,000 troops. The western states on January $29^{\text {th }}$ in a donor conference held in Adis Abbaba offered $\$ 455$ million to support the operation of AFISMA. ${ }^{62}$ Of this amount they intended to finance the rebuilding, training, and installment of the Malian army.

According to the African Union, this amount will not be sufficient to operate AFISMA, with an estimated cost of about USD 950 million. ${ }^{63}$ Will the international community pay for this, will the Africans be able to take this mission to completion and stabilize the region? We will only be able to see this after the withdrawal of French troops.

\section{Organized by the European Union Training Mission ${ }^{64}$}

In the EU meeting in 2012 mid-October, the representatives of the 27 member states voted to support Mali's territorial integrity and the restoration of the democratic governance and rule of law. Therefore, the initiation of a training mission has been approved. On January $17^{\text {th }}$

2013, the meeting held by foreign ministers of the European countries endorsed the mission launch in Mali, and promised support for the African-led operation. With a budget of 12.3 million Euros planned for 15 months, the mission commander will be the French Brigadier General Francois Lecointre, who conducted a field pre-assessment on January $20^{\text {th }}$ and 23rd in Mali to learn about the necessary conditions to initiate the mission. According to the plan 250 trainers, 200 soldiers responsible for logistics, guarding and protection get a role in the EU's new mission. ${ }^{65}$ The mission's command will be in Bamako, but the training activities will be conducted in other areas of the country. The EU will pay only the costs of the oper- ation, while the nations will provide the equipment, salaries and the travelling expenses of the troops sent there. Hungary has declared at a forum that although Africa does not belong to its closer sphere of interest, it will send 10 military trainees into the operation (6 snipers,

3 medics and a staff officer). ${ }^{66}$

61 http://www.trust.org/alertnet/news/un-chief-warns-against-un-logistical-support-for-mali-war/ (downloaded: 24012013 )

$62 \mathrm{http}: / /$ summits.au.int/en/20thsummit/events/donors-conference-mali (downloaded: 3001 2013)

63 http://www.bbc.co.uk/news/world-africa-21256781 (downloaded: 3001 2013)

64 The operation by day can be reached in this page: http://news.silobreaker.com/eutm-11_98654715

65 http://eeas.europa.eu/csdp/missions_operations/eutm-mali/final_factsheet_eutm_mali_en.pdf (downloaded: 26012013 )

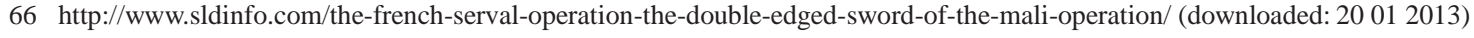

BESENYÖ János: War at the Background of Europe: The Crisis of Mali

\section{Conclusion}

The question is not whether the military operation will be successful but how the winners will want to consolidate and

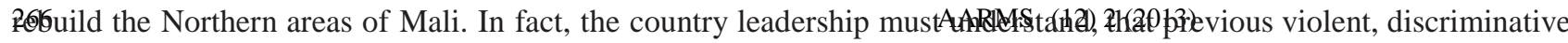
methods can not "modernize" the Tu- areg society, because it always leads to a conflicted situation. The historical experience of the Tuaregs understandably rejects the government authorities, and distrusts their activities. This is why the government needs to find a new approach to the northern region -and the Tuaregs in it-and its remedy for their problems, and also a constructive dialogue with them. This may include granting them limited autonomy, or the transformation of government structure to a functional federal state in which the ethnic groups would have greater autonomy and political representation. This would require a reliable, stable functioning government in Bamako that supports all segments of the society. If this will not be realized then in that case Mali should prepare in advance for the next and subsequent Tuareg uprisings.

After the reconstruction of the country, regional cooperation also needs to be improved between countries, in which the international community needs to take an active part. They need to eradicate the weapon and drug smuggling in the area and create programs for nomads which will replace their income from these activities. They need to establish and effectively implement a country-wide disarmament, demobilization and reintegration program in which they disarm the 
various armed groups with special attention paid to the question of child soldiers recruited by the Islamic extremist. At the same time they need to pursue the training and equipping of the Sahel countries' forces, so they will be able to effectively take action against the smugglers and the Islamic extremists. The armed forces should be kept away from politics and used only for military use, border patrol and other professional activities.

Also, it raises the question, what will happen with the Islamists who have fled; where else will they "exploit" their military experience gained in Mali? In how much time will they be able to reorganize their groups to cause problems in other West African counties, where the West has significant political and economic interests? When will they be able to carry out ter- rorist acts, in either France or in other European countries that are involved in the operations, as they previously have threatened ${ }^{67}$ Considering the previous years events, unfortunately the western world must be prepared for these events.

\section{References}

ABDERRAHMANE, A. (2012): Why Military Intervention in Mali Would be a Mistake, http://www.issafrica.org/iss_today.php?ID=1558\%2634

ACAPS (2012): Northern Mali conflict \& Food insecurity, Disasters Needs Analysis, Geneva: ACAPS Office http://www.ecbproject.org/northern_mali_disaster_needs_analysis_conflict_food_insecurity_nov_2012[1].pdf (downloaded: 11012013$)$

AFRICAN UNION (2013): Donors' Conference on Mali, Ethiopia: Addis Ababa, 29 January 2013, Press release N. 6/2013 http://summits.au.int/en/20thsummit/events/donors-conference-mali

67 http://www.guardian.co.uk/world/2013/jan/14/mali-conflict-france-gates-hell (downloaded: 20012013 ) BESENYÖ János: War at the Background of Europe: The Crisis of Mali

AFRIQUEJET (2013): Mali intervention force: ECOWAS mobilises more troops, logistic support http://www.afriquejet.com/20130120227/Mali-intervention-force-ECOWAS-mobilises- more-troops-logistic-support.html

AL JAZEERA (2013): Interactive: Mali speaks, 21 January http://www.aljazeera.com/indepth/interactive/2013/01/201312113451635182.html

AMNESTY INTERNATIONAL (2012a): Mali: Civilians Bear the Brunt of the Conflict http://www.unhcr.org/refworld/pdfid/505c16fe2.pdf

AMNESTY INTERNATIONAL (2012b): Mali: Five months of crisis http://reliefweb.int/sites/reliefweb.int/files/resources/afr370012012en.pdf

APPLEBAUM, A. (2013): The world's new superpower, National Post Jan. 28 http://fullcomment.nationalpost.com/2013/01/28/anne-applebaum-on-europe-the-worlds- new-superpower/

ARIEFF, A. (2013): Crisis in Mali, CRS report, January 14 http://www.fas.org/sgp/crs/row/R42664.pdf

BBC NEWS (2012): Mali: Islamists seize Gao from Tuareg rebels, 28 June http://www.bbc.co.uk/news/world-africa-18610618

BBC NEWS (2013a): France Rafale jets target Gao in Eastern Mali, 13 January http://www.bbc.co.uk/news/world-europe-21002918

BBC NEWS (2013b): Mali conflict: France says its troops now in Kidal, 30 January http://www.bbc.co.uk/news/world-africa-21256781

BERTELSMANN STIFTUNG (2012): Mali Country Report, Gütersloh: Bertelsmann Stiftung, 39 p.

BESENYŐ J. (2008): Az afrikai konfliktusok és kezelésük sajátosságai, a békefenntartó műveletek során szerzett tapasztalatok, Felderítö Szemle VII. évfolyam, 3. szám, pp. 5-15.

BESENYÖ, J. (2010): Az Al-Kaida térnyerése a Maghreb régióban, Seregszemle VIII. évfolyam, 3. szám, július-szeptember, pp. 148-154.

http://www.honvedelem.hu/container/files/attachments/28301/s_sz_2010_3.pdf

BESENYÖ J. (2011): Terrorexport a Szaharába — Al-Káida klón a sivatagban, Földgömb XIII (XXIX) évfolyam, 5. lapszám, 257. füzet, július-augusztus, pp. 38-41.

BESENYŐ J. (2012): Újabb válsággóc Afrikában: Mali, Honvédségi Szemle 140. évfolyam, 5. szám, pp. 10-12. http://hu.scribd.com/doc/110816155/honvedsegi-szemle-2012-05

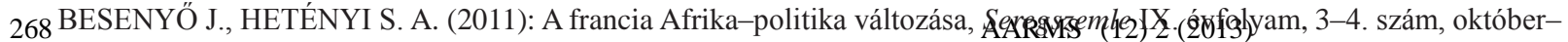
december, pp. 199-08. http://www.honvedelem.hu/container/files/attachments/28300/seregszemle_2011_3.pdf

BESENYÖ J., MARSAI, V. (2012): Országismertető: Líbia, Székesfehérvár: MH Összhaderőnemi Parancsnokság Tudományos Tanács

BONDERSHOLT, S. F., GYLDENHOLM, K. C. K. (2012): Conflict in North Mali - Tuareg Livelihood, Roskilde University: International development Studies

BORGER, J. (2013): Who is doing what?, The Guardian 16 January http://www.guardian.co.uk/world/2013/jan/15/mali-who-is-doing-what

BOUKHARS, A. (2012): The paranoid neighbors, Algeria and the conflict in Mali, The Carnegie Papers

CBSNEWS (2012): African Union asks UN for military invention in Mali, AP News, 14 November http://www.cbc.ca/news/world/story/2012/11/14/un-african-union-mali.html

CENCIOTTI, D. (2013): Nigerian gunships, European airliftes (and weaponized U.S. drones) join Mali air war http://theaviationist.com/2013/01/24/mali-air-war-update/ CHRISAFIS, A. (2013): Mali: French

troops in direct combat with insurgents 'within hours', 
The Guardian 16 January, http://www.guardian.co.uk/world/2013/jan/16/french-ground-operations-mali-underway

CHRISAFIS, A., HIRSCH, A. (2013): France expected to more than triple, The Guardian, 15

January http://www.guardian.co.uk/world/2013/jan/15/french-troops-triple-mali

CIA (2013): The World factbook: Mali https://www.cia.gov/library/publications/the-worldfactbook/geos/ml.html (downloaded: 1301 2013)

BESENYÖ János: War at the Background of Europe: The Crisis of Mali

CICHE, M. (2010): Country desk study: Mali

DELAPORTE, M. (2013): The French "Serval Operation" The double edged sword of the Mali operation, http://www.sldinfo.com/the-french-serval-operation-the-double-edged-sword- of-the-mali-operation/

DIALLO, S. (2008): Pastoral nomadic Tuareg in Transition: The case of Igorareine Tuareg in Echagh, Northern Mali, University of Tromso: Faculty of Social Sciences

DIARRA, O. (2012): Insecurity and instability in the Sahel region: The Case of Mali, Carlisles (Pennsylvania): United States Army War College

DOYLE, M (2013): Mali conflict: French troops 'seize' Diabaly and Douentza, BBC News 21 January, http://www.bbc.co.uk/news/world-africa-21121262

EUROPEAN UNION EXTERNAL ACTION (2013): EU Training Mission in Mali, 13 January http://eeas.europa.eu/csdp/missions_operations/eutm-mali/final_factsheet_eutm_mali_en.pdf

EXPATICA.com (2013): Two weeks of French intervention in Mali http://www.expatica.com/fr/ news/french-news/two-weeks-of-french-intervention-in-mali_256661.html

FORMANEK, I., SMITH-PARK, L., NETTO J. (2013): Mali's famed Timbuktu without water, other services, CNN, 25 January http://edition.cnn.com/2013/01/24/world/africa/mali- military-offensive/index.html?hpt=hp_t3

HIRSCH, A. (2013): Mali: French hunt fugitive rebels after seizing Diabaly from Islamists, The Guardian 21 January http://www.guardian.co.uk/world/2013/jan/21/mali-french-seize- diabaly-rebels

HUMAN RIGHTS WATCH (2012): Mali: War crimes by Northern rebels, 30 April http://www.hrw.org/node/106800

HUMPREYS, M., ag MOHAMED, H. (2003): Senegal and Mali, Columbia: Columbia University http://www.columbia.edu/ mh2245/papers1/sen_mali.pdf

ILAHIANE, H. (2006): Historical Dictionary of the Berbers (Imazighen), The Scarecrow Press Inc., $359 \mathrm{p}$.

IMPERATO, P. J. (1996): Historical Dictionary of Mali, Third edition, Scarecrow Press

INTERNATIONAL CRISIS GROUP (2012): Mali: Avoiding escalation, Africa Report №189 18 July

INTERNATIONAL MONETARY FOUND [IMF] (2011): Mali: Poverty Reduction and Strategy Paper-2010 Progress Report, Washington: Washington: IMF External Relations Department http://www.imf.org/external/pubs/ft/scr/2011/cr11372.pdf (downloaded: 1301 2013) https://doi.org/10.5089/9781463929169.002

INTERNATIONAL MONETARY FOUND (2012): Statement at the conclusion of an IMF mission to Mali, Washington: IMF External Relations Department http://www.imf.org/external/np/sec/pr/2012/pr12437.htm (downloaded: 1301 2013)

KEITA, K. (1998): Conflict and conflict resolution in the Sahael, the Tuareg insurgency in Mali, USA Army Collage: Strategic Studies Institute,

LECOCQ, B., SCHRIJVER, P. (2007): The war on terror in a haze of dust: potholes and pitfalls on the Saharan fronts, Journal of Contemporary African Studies Vol. 25, Issue 1, January, pp.

141-166 https://doi.org/10.1080/02589000601157147

LOHMAN, A. (2011): Who owns the Sahara? Old conflicts, New menaces: Mali and the central Sahara between the Tuareg Al Qaida and organized Crime, Berlin: Friedrich Ebert Stiftung

MANN, G. (2013): Mali: France facing a formidable enemy, The Guardian, 15 January http://www.guardian.co.uk/world/2013/jan/15/mali-france-military-intervention

MARSAI V. (2013): Külföldi katonai beavatkozás Maliban — az Operation Serval és háttere, Stratégiai Védelmi Kutató Központ Elemzések 1. szám, http://hhk.uni-nke.hu/downloads/ kozpontok/svkk/Elemzesek/2013/SVKK_Elemzesek_2013_1.pdf

McGREGOR, A. (2012): Foreign intervention in Mali seek to exploit divisions in rebel ranks, Terrorism Monitor Volume X, Issue 13, June 29 http://www.jamestown.org/uploads/media/TM_010_Issue13.pdf

METCALF, S. (2012): Iyad Ag Ghaly, Mali’s islamist leader, BBC News, 17 July http://www.bbc.co.uk/news/world-africa-18814291

BESENYÖ János: War at the Background of Europe: The Crisis of Mali

AARMS (12) 2 (2013)

269

MORGAN, A. (2013): Mali's rebels hold the advantage in a ground war on desert plains, The Guardian 16 January http://www.guardian.co.uk/world/2013/jan/16/mali-french-ground-war

MOUAKI, S. (2012): Christian refugees flee Mali as Ansar Dine escalates terror, Al Monitor http://www.al-monitor.com/pulse/security/01/08/torture-and-violence-against-opp.html

OUEDRAOGO, B. (2012): Mali's secular rebels splinter, AP News, 24 September, http://bigstory.ap.org/article/ap-interview-malis-secular-rebels-splinter

REUTERS (2013): UN chief warns against UN logistical support for Mali war, 23 January http://www.trust.org/alertnet/news/un-chief-warns-against-un-logistical-support-for-mali-war/

SCELTA, G. F. (2002): The Caligraphy and architecture of the nomadic Tuareg within the geometric context of Islam

SCHRAEDER, P. J. (2011): Traditional conflict medicine? Lessons from putting Mali and other African countries on the road to peace, Nordic Journal of African Studies Volume 20 Issue 2, pp. 177-202

TISDALL, S. (2013): France's lonely intervention in Mali, The Guardian, 14 January 
http://www.guardian.co.uk/commentisfree/2013/jan/14/france-lonely-intervention-mali

TRAN, M. (2013): Mali: a guide to the conflict, The Guardian, 16 January

http://www.guardian.co.uk/world/2013/jan/16/mali-guide-to-the-conflict

UN SECURITY COUNCIL (2012): Security Council Authorizes Deployment of African-led International Support Mission in Mali for Initial Year-Long Period, Resolution 2085

(2012) Stresses Need to Further Refine Military Planning, New York: Department of Public Information, News and Media Division http://www.un.org/News/Press/docs/2012/sc10870. doc.htm (downloaded: 2001 2013) 